\title{
INFECTIVE ENDOCARDITIS OF AORTAL AND MITRAL HEART VALVES AT CHRONIC UROSEPSIS
}

\author{
I.Ya.Horbachevsky Ternopil National Medical University, Ternopil, \\ Ukraine
}

Инфекционный эндокардит (ИЭ) - это мультисистемное заболевание, которое возникает в результате инфекции, обычно бактериальной, эндокардиальной поверхности сердца. Описан клинический случай больного, поступившего в отделение сердечно-сосудистой хирургии с диагнозом активного инфекционного эндокардита аортального и митрального клапанов, с сопутствующим хроническим уросепсисом. По данным бактериологического исследования установлена этиологическая связь происхождения патологии сердца с хроническим уросепсисом. А также описаны результаты современных методов визуальной диагностики, на основании которых был сформирован предоперационный диагноз. Проведено протезирование аортального клапана On-X 19 и митрального клапана On-X 27/29. Оценен послеоперационный период и особенности его течения, учитывая этиологическую природу инфекционного эндокардита. Этот клинический случай наглядно показывает, что любой хронический инфекционный процесс может вызвать поражение эндокарда даже при медленно развивающихся процессах нетипичного происхождения, например, мочевыделительной системы. Таким образом, это свидетельствует о том, что необходимо тщательно и всесторонне обследовать пациента с острыми и хроническими инфекционными процессами на инфекционный эндокардит, поскольку на ранних стадиях заболевание проявляется постепенно; и это помогает предотвратить серьезные осложнения в будущем.

Ключевые слова: инфекционный эндокардит, хронический инфекционный процесс мочевыделительной системы, хронический уросепсис, коморбидная патология, хирургическое лечение приобретенного порока сердиа

Infective endocarditis (IE) is a multisystem disease that results from an infection, usually a bacterial one, on the endocardial heart surface. A clinical case of a patient admitted to the department of cardiovascular surgery with a diagnosis of active infectious endocarditis of the aortic and mitral valves with concomitant chronic urosepsis is described. According to the bacteriological study an etiological relationship between the origin of heart pathology and chronic urosepsis was established. The results of current methods of visual diagnostics on the basis of which the preoperative diagnosis was formed are also described. Prosthetics of the On-X 19 aortic valve and On-X 27/29 mitral valve was performed. The postoperative period and the features of its course were assessed, taking into account the etiological nature of infective endocarditis. This clinical case clearly shows that any chronic infectious process can cause damage to the endocardium, even with slowly developing processes of atypical origin, for example, the urinary system. Thus, this case indicates that it is necessary to examine a patient with acute and chronic infectious processes carefully and comprehensively for infective endocarditis, since in the early stages the disease manifests itself gradually; and this helps prevent serious complications in the future.

Keywords: infective endocarditis, chronic infectious process of the urinary system, chronic urosepsis, comorbid pathology, surgical treatment of acquired heart defect

Novosti Khirurgii. 2021 Nov-Dec; Vol 29 (6): 754-757

The articles published under CC BY NC-ND license Infective Endocarditis of Aortal and Mitral Heart Valves at Chronic Urosepsis T.V. Romaniuk, R.I. Lekan, I.I. Loyko

\section{Introduction}

Infective endocarditis (IE) is a multisystem disease that results from an infection, usually a bacterial, of the heart endocardial surface. In a systematic review, the overall incidence of IE was up to 59 hospitalizations per 100,000 people per year in developing countries [1], while data are available for 3.5-10 hospitalizations per 100,000 people per year in the most high income countries [2] The deaths from IE without treatment, do not differ significantly across countries. At the same time, even with the best available therapy, current death rates from IE are approximately $29-40 \%$ [3].
It has been reported that more than one third of IE cases in recent years were associated with the provision of medical care (nosocomial or outpatient assistance) [4]. There is evidence of an infectious cardiac inflammatory process development with chronic persistent pathologies of other organs and systems [5]. The more frequent spread of inflammatory diseases in different organs and systems, as well as the grouping of several of these predisposing factors with age, probably explains the increased incidence of infective endocarditis among people aged 65 years and older [2]. Therefore, there is a need to determine the etiological component of patient's comorbid pathology development. 


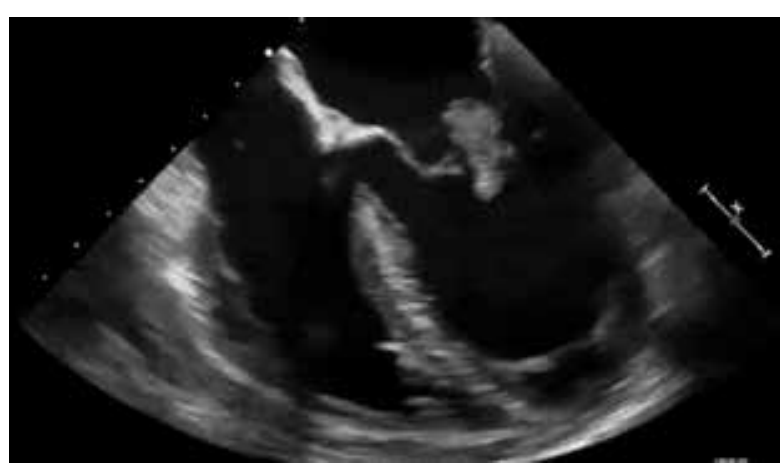

Fig. 1 . Echocardiography. Vegetation prolapse of the mitral valve into the left atrial cavity due to retrograde blood flow.

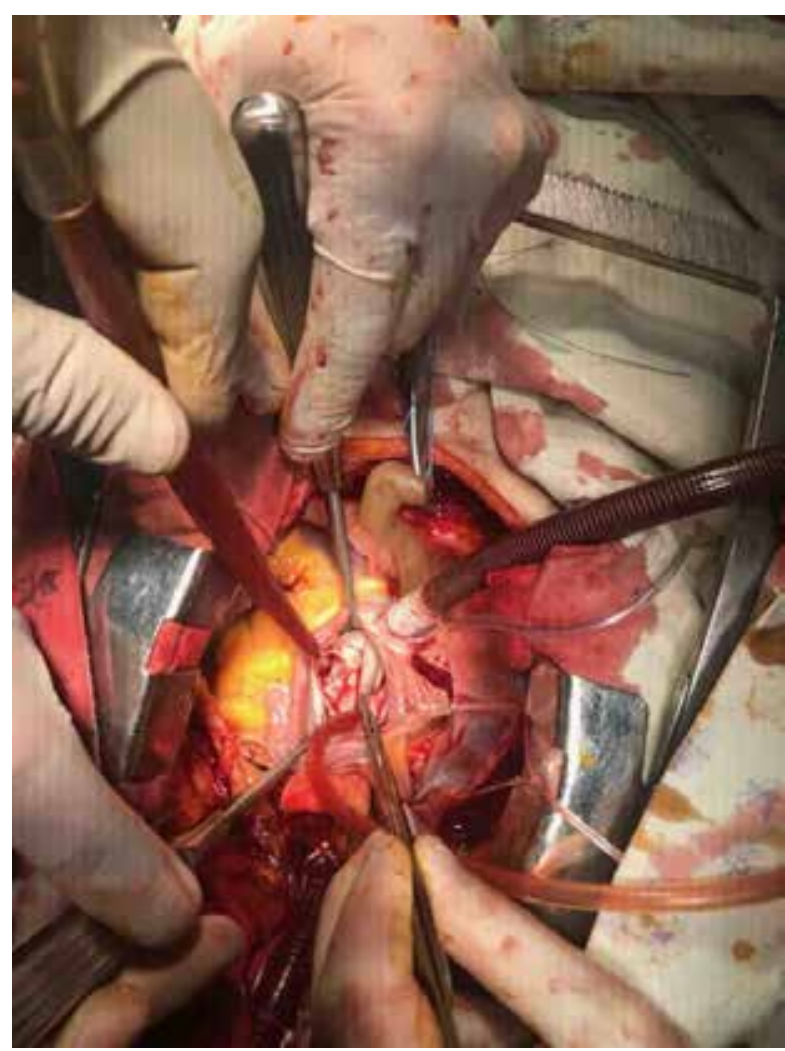

Fig. 2. Surgery to remove the aortic cusps from the valve.

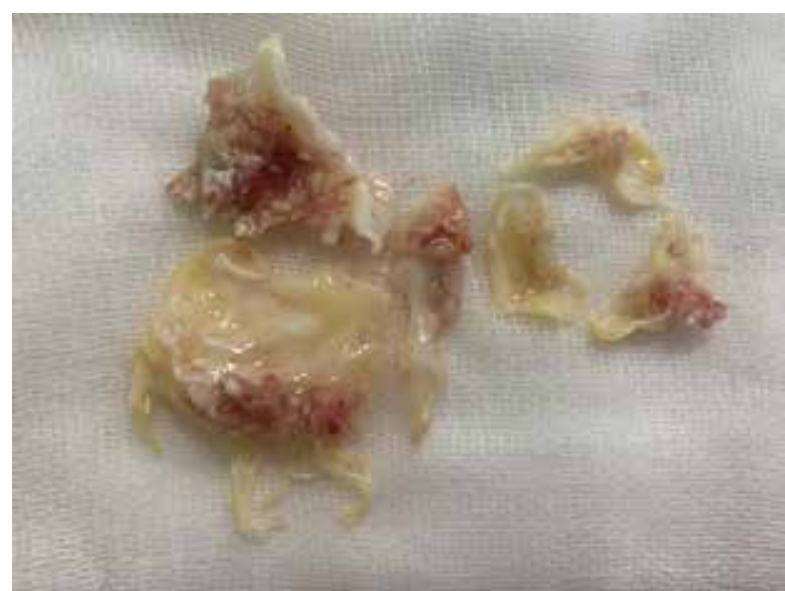

Fig. 3. The cusps of the aortic and mitral valves affected by vegetation and infection.
Objective. To determine the pathogenetic relationship of two coexisting anatomically different urological and cardiac pathologies in a specific clinical case.

\section{A clinical case}

A 76 year-old female was admitted to the department of cardiovascular surgery with a preliminary diagnosis - infective endocarditis involving mitral and aortic valves.

Concomitant aortic defect with a predominance of stage II valvular insufficiency. Mitral valve regurgitation (III degree). Pulmonary hypertension (stage II). Heart failure stage (IIa), NYHA stage II functional class

From the anamnesis it is known that the patient has been ill for the last 6 months with complaints of intermittent subfebrile condition, periodic shortness of breath, predominantly at rest and general weakness.

The development of the disease began with an inflammatory process of the urinary tract lasting for several weeks with such clinical manifestations as pain in the lumbar region, painful urination and visual changes in urine (turbidity, sediment), which the patient paid attention to.

On the objective clinical examination the following diagnosis was made: chronic urethrocystitis, acute stage. Chronic urosepsis. Stage III chronic kidney disease, stage I chronic renal failure. Ifectious endocarditis of the aortic and mitral valves. Concomitant aortic defect with a predominance of stage II valvular insufficiency. Insufficiency of the mitral valve of the III degree. Pulmonary hypertension stage II. Heart failure stage IIa, NYHA stage II functional class. Chronic pancreatitis, remission stage, with polycystic pancreas. The diagnosis was confirmed by echocardiography (Fig. 1), kidney ultrasound, computed tomography of the chest and abdomen. CT coronary angiography excluded coronary artery disease. Ultrasound examination of the shin and neck vessels excluded stenotic-occlusive lesions.

An additional sampling of blood and urine was carried out for bacteriological culture. There was no microbial growth in the blood, but the following organisms were found in the urine: viridans group streptococci (VGS), E. coli, proteus vulgaris.

After the examination and the necessary preoperative preparation, it was decided to perform the following surgical measures: prosthetics of the On-X 19 aortic valve and On-X 27/29 mitral valve. Within the operation, the cusps of the aortic and mitral valves were removed (Fig. 2, 3), local anesthetic agents have been applied on the fibrous rings of the heart. The cusps of both valves 
were sent for histopathological analysis, and the vegetation of the valves was sent for bacteriological examination.

In the bacteriological culture, the growth of viridans group streptococci (VGS) was found, which indicates the urological route of infection.

The postoperative period was rather difficult. From the second day, chronic renal failure increased sharply to stage III, which was confirmed by fragmentation of vegetation during the operation; with a sudden cardiac impairment, leading to clinical death on the third day of the postoperative period. After resuscitation, vital functions were restored, intensive therapy continued. By the 8-10th day after the operation, the protein level and renal excretory function were compensated. Sicksinus syndrome persisted until day 10 and then the normal sinus rhythm was restored and epicardial electrodes were removed.

\section{Discussion}

Scientific literature data testify about cases of the development of infectious endocarditis in patients with inflammatory pathology of the urinary system [6]. But the number of the described clinical cases with the proven connection of the infectious process in different body systems is not so great [5].

According to the data of our clinical study, two infectious processes were diagnosed: in the endocardium - damage to the aortic and mitral valves, which was significantly manifested in the patient, and chronic bacteriological inflammation of the urinary tract, which was the patient's main complaint over the past 6 months. A more detailed bacteriological study proved that both infectious processes have a common pathogenesis. Considering the onset of the disease from the urinary tract and the etiological factor of the disease with viridans streptococci (VGS), the genitourinary nature of the disease was established.

Namely, this makes this clinical case interesting due to the possibility of developing a serious complication - an acquired heart defect in very common inflammatory urological diseases. The choice of effective antibiotic therapy is also of great significance, taking into account the specific etiological component [7].

Conclusion

A clinical case of infectious endocarditis, which developed as a result of chronic urosepsis, is presented. The process of diagnostics and treatment of this patient is described. According to the bacteriological study described in this article the revealed flora on the endocardium is identical to the microflora of the genitourinary system of the given patient. That allows asserting the etiological relationship of infectious pathologies in different systems of the patient's body.

This clinical case shows that any chronic infectious process can cause damage of the endocardium, even slowly developing process of atypical origin, for example, the urinary system.

The clinical case also indicates that it is necessary to examine a patient with acute and chronic inflammatory processes carefully and comprehensively for the presence of active infectious endocarditis, since in the early stages this disease manifests itself gradually, and the proposed diagnostic approach can potentially prevent serious complications of IE in such patients.

\section{Funding}

The work was carried out in accordance with the plan of scientific research of the university. The authors did not receive any financial support from third parties.

\section{Conflict of interests}

There is no any conflict of interests.

\section{Ethical aspects}

Ethics committee approval

The study was approved by the Ethics Committee of Ternopil National Medical University.

\section{Informed consent}

The patient gave permission for the publication and placement on the Internet of information about the nature of the diseases, the treatment carried out and its results for scientific and educational purposes.

\section{ЛИТЕРАТУРА}

1. Sunil M, Hieu HQ, Arjan Singh RS, Ponnampalavanar S, Siew KSW, Loch A. Evolving trends in infective endocarditis in a developing country: a consequence of medical progress? Ann Clin Microbiol Antimicrob. 2019 Dec 17;18(1):43. doi: 10.1186/ s12941-019-0341-x

2. Leroy O, Georges H, Devos P, Bitton S, De Sa N, Dedrie C, Beague S, Ducq P, Boulle-Geronimi C, Thellier D, Saulnier F, Preau S. Infective endocarditis requiring ICU admission: epidemiology and prognosis. Ann Intensive Care. 2015 Dec;5(1):45. doi: 10.1186/ s13613-015-0091-7

3. Heredia-Rodríguez M, Hernández A, BustamanteMunguira J, Álvarez FJ, Eiros JM, Castrodeza J, Tamayo E. Evolution of the Incidence, Mortality, and Cost of Infective Endocarditis in Spain Between 1997 and 2014. J Gen Intern Med. 2018 Oct;33(10):16101613. doi: $10.1007 / \mathrm{s} 11606-018-4514-7$

4. Benito N, Pericas JM, Gurguí M, Mestres CA, 
Marco F, Moreno A, Horcajada JP, Miry JM. Health Care-Associated Infective Endocarditis: a Growing Entity that Can Be Prevented. Curr Infect Dis Rep. 2014 Nov;16(11):439. doi: 10.1007/s11908-014-0439-4

5. Diallo K, Ferrand J, Goehringer F, Selton-Suty C, Folliguet T, Alauzet C, Lozniewski A. The Brief Case: An Unusual Cause of Infective Endocarditis after a Urological Procedure. J Clin Microbiol. 2018 Jun 25;56(7):e01400-17. doi: 10.1128/JCM.01400-17

6. Mohee A, West RM, Baig W, Eardley I. A casecontrol study: Are urological procedures risk factors for the development of infective endocarditis? BJU International. 2014 Jul;103(1). doi: 10.1111/bju.12550

7. Karthikesalingam A, Turner W, Wiseman O, Dutka D. Antimicrobial prophylaxis against infective endocarditis before urological surgery. BJU Int. 2009 Jan;103(1):4-6. doi: 10.1111/j.1464-410X.2008.07937.x

\section{REFERENCES}

1. Sunil M, Hieu HQ, Arjan Singh RS, Ponnampalavanar S, Siew KSW, Loch A. Evolving trends in infective endocarditis in a developing country: a consequence of medical progress? Ann Clin Microbiol Antimicrob. 2019 Dec 17;18(1):43. doi: 10.1186/ s12941-019-0341-X

2. Leroy O, Georges H, Devos P, Bitton S, De Sa N, Dedrie C, Beague S, Ducq P, Boulle-Geronimi C,

\section{Адрес для корреспонденции}

46020, Украина,

г. Тернополь, ул. Майдан Воли, д. 1,

Тернопольский национальный медицинский университет имени И.Я. Горбачевского, кафедра хирургии № 2, тел.: +380637143228,

e-mail: Loikoii@tdmu.edu.ua,

Лойко Игорь Игоревич

\section{Сведения об авторах}

Романюк Тарас Владимирович, к.м.н., доцент, кафедра хирургии № 2, Тернопольский национальный медицинский университет имени И.Я. Горбачевского, г. Тернополь, Украина.

https://orcid.org/0000-0001-9279-3711

Лекан Роман Иосифович, д.м.н., профессор, кафедра хирургии № 2, Тернопольский национальный медицинский университет имени И.Я. Горбачевского, г. Тернополь, Украина.

https://orcid.org/0000-0002-6385-050X

Лойко Игорь Игоревич, к.м.н., доцент, кафедра хирургии № 2, Тернопольский национальный медицинский университет имени И.Я. Горбачевского, г. Тернополь, Украина.

https://orcid.org/0000-0003-2967-1054

\section{Информация о статье}

Поступила 25 ноября 2020 г.

Принята в печать 29 ноября 2021 г.

Доступна на сайте 1 ноября 2021 г.
Thellier D, Saulnier F, Preau S. Infective endocarditis requiring ICU admission: epidemiology and prognosis. Ann Intensive Care. 2015 Dec;5(1):45. doi: 10.1186/ s13613-015-0091-7

3. Heredia-Rodríguez M, Hernández A, BustamanteMunguira J, Álvarez FJ, Eiros JM, Castrodeza J, Tamayo E. Evolution of the Incidence, Mortality, and Cost of Infective Endocarditis in Spain Between 1997 and 2014. J Gen Intern Med. 2018 Oct;33(10):16101613. doi: $10.1007 / \mathrm{s} 11606-018-4514-7$

4. Benito N, Pericas JM, Gurguí M, Mestres CA, Marco F, Moreno A, Horcajada JP, Miry JM. Health Care-Associated Infective Endocarditis: a Growing Entity that Can Be Prevented. Curr Infect Dis Rep. 2014 Nov;16(11):439. doi: 10.1007/s11908-014-0439-4

5. Diallo K, Ferrand J, Goehringer F, Selton-Suty C, Folliguet T, Alauzet C, Lozniewski A. The Brief Case: An Unusual Cause of Infective Endocarditis after a Urological Procedure. J Clin Microbiol. 2018 Jun 25;56(7):e01400-17. doi: 10.1128/JCM.01400-17

6. Mohee A, West RM, Baig W, Eardley I. A casecontrol study: Are urological procedures risk factors for the development of infective endocarditis? BJU International. 2014 Jul;103(1). doi: 10.1111/bju.12550

7. Karthikesalingam A, Turner W, Wiseman O, Dutka D. Antimicrobial prophylaxis against infective endocarditis before urological surgery. BJU Int. 2009 Jan;103(1):4-6. doi: 10.1111/j.1464-410X.2008.07937.x

\section{Address for correspondence}

46020, Ukraine,

Ternopil, Maydan Volia Str., 1,

I.Ya. Horbachevsky Ternopil

National Medical University,

Surgery Department No2,

ел. +380637143228 ,

e-mail: Loikoii@tdmu.edu.ua,

Loyko Ihor I.

Information about the authors

Romaniuk Taras V., PhD, Associate Professor, the Surgery Department No2, I. Horbachevsky Ternopil National Medical University, Ternopil, Ukraine.

https://orcid.org/0000-0001-9279-3711

Lekan Roman I., MD, Professor, the Surgery Department No2, I. Horbachevsky Ternopil National Medical University, Ternopil, Ukraine.

https://orcid.org/0000-0002-6385-050X

Loyko Ihar I., PhD, Associate Professor, the Surgery Department No2, I. Horbachevsky Ternopil National Medical University, Ternopil, Ukraine.

https://orcid.org/0000-0003-2967-1054

\section{Article history}

Arrived: 25 November 2020

Accepted for publication: 29 November 2021

Available online: 1 January 2022 